\title{
Islamic Tolerance and the West: Early Encounters and Influences
}

\author{
FAHIMEH NASERI $\mathbf{1}$
}

\begin{abstract}
This article is an attempt to explore the conception of tolerance as an inherent principle of Islam, and to show how it was practised when Islam was a political and cultural power. It will be argued that Muslim practice of religious and cultural tolerance proves to be one of the very first examples of multiculturalism and inclusion. The early instances of delivering this Islamic value in Spain, Turkey and during the Second Crusade provide evidence for the Muslim contribution to religious and cultural inclusion which is part of the belief system of Muslims.
\end{abstract}

Keywords: Crusades, interreligious contact, Islam, religious tolerance, the West

Arguments about the relationship between western and Islamic worlds tend to acknowledge the Muslim contribution towards the advance of science and technology, but are hesitant to recognise their contribution to the establishment of religious and cultural tolerance. The focus on the differences between the Western and Islamic worlds, especially in the realm of social and political values, has presented Western civilization standing for individual freedom, secularism and tolerance; while Islamic civilization has been increasingly associated with collective rights, individual obligations, despotism and intolerance. The impact of ideas such as the "clash of civilizations" of Samuel Huntington (1996) who did not believe in any collaboration and similar grounds between the East and the West, has added a new dimension to the predominant dichotomy between the two supposedly opposite poles. The tendency was then to focus on the differences between these realms to show that the clash is natural. Nevertheless, a look at the history of the relationship between the East and the West, and the many cultural, artistic and scientific exchanges would show that at the time when Islam was in power, it was the pervasive and the primary instigator of religious, cultural and political inclusion into society. This is supported by looking into the early encounters between the West and Islam to find out more about their interactions and influences. It will be shown in the rest of this article that under Muslim rule, different religious minorities in Spain enjoyed peaceful coexistence during the reign of Abd al-Rahman (912-961AD), his son (961-976AD) and grandson (976-1009AD) as well as during the Ottomans rule in Turkey. These are among the longest periods of the encounter and exchange between Islam and the West at a time when Muslim power was at its peak. This creates a good context in which toleration was practised in an unprecedented way that many aspects of it have not yet been fully recognised.

The examples given are not to suggest that the rule of Islam over these countries created a utopia there as, for instance, though Abd al-Rahman was lenient towards non-Muslim minorities, he repelled the Fatimids for political reasons. The present study hopes to refute arguments about the absence of patterns and conceptions of cohesion, integration, multiculturalism, tolerance and inclusivity in Islam as a religion, and the impossibility of achieving it. The argument also would shed light on the ways that religious and cultural values travelled and created new patterns which have been shaping our common ground of existence. In what follows, I will define the conception of tolerance in Islam, and continue with an

\footnotetext{
${ }^{1}$ Fahimeh Naseri, Ph.D., Assistant Professor of English Language and Literature at the Dept. of English Language and Literature, Persian Gulf University, BUSHEHR, Iran, email: Paribahieh@gmail.com.
} 
exploration of the ways it worked towards establishing multiculturalism and the advancement of knowledge.

Following my argument here, the meaning of the conception of tolerance, as Benthall (2005: 16) thinks, rests on two points: first, I negatively appraise something that others do, but decide not to interfere with it; and second on a relationship of domination, forbearance and the permission given by the adherents of a dominant religion for other religions to exist, even though the latter are looked on with disapproval as inferior, mistaken or harmful. Tolerance may be distinguished from cultural pluralism and relativism, with their egalitarian, antihierarchic leanings. In Islam, the meaning and practice of tolerance can be drawn from the Quran, tradition and the accepted wisdom of theologians and Muslim thinkers. In general, this conception can be defined as a pact which shows the relationship between a Muslim State and non-Muslims in its realm. According to this pact Peoples of the Book or dhimma, who are Jews, Christians and Sabians, would be protected, could practise their own religion, preserve their own places of worship, and run some of their own affairs provided they were loyal to Islamic political authority. In the Quran, religious tolerance is indicated in verses such as (5:72) that reads, "those who believe, those who follow Jewish scriptures, the Christians, the Sabians, and any who believe in God and the Last Day, and do good, all shall have their reward with their Lord and they will not come to fear or grief". Verses like this recognise the salvific value of other monotheistic religions and ascribe to them the status of dhimma. In the early years of Islam (660-670AD) dhimma had to pay poll tax, but gradually this system was abolished. The justification behind it was that Muslims had to pay zakat and contributions towards the expenses for jihad, while non-Muslims did not have to. The poll tax was their contribution towards the maintenance of society then. Curiously enough, the practice of paying poll tax in return for protection by the state is similar to Queen Elizabeth I's Act of Conformity in 1558AD, according to which people had to attend the church on Sundays or alternatively pay fines in order to be protected by the state and avoid persecution. Compared to the years of Mary's reign, when Protestants were heavily persecuted, Queen Elizabeth I's Act was a relief to part of the Catholic adherents who could afford to pay fines and be protected in their homeland. Whether or not Queen Elizabeth was inspired by the Islamic way of treating non-practitioners of the dominant religion leaves much to be investigated. Nevertheless, it seems unlikely to think that she was unaware of how non-Muslims were treated in a Muslim state, because by the sixteenth century Islam was very well known in Europe, and England held good relations with two Muslim empires of the time, the Persian and the Ottoman. By the time of Queen Elizabeth I, the dhimma included almost all adherents of monotheistic religions who did not have to pay tax.

The inclusion of the adherents of other religions into dhimma was initially justified by the Iranian Indologist, Abu Reyhan al-Biruni (937-1048AD). In his book Kitab-al-Hind, he argued in favour of Hindus being accepted as dhimma. In early seventeenth century, this inclusion helped the Emperor Akbar to unite the vast and diverse realm of India during his reign. Over time the followers of other denominations such as Zoroastrians, Buddhists, Manicheans, and indigenous cosmologies of Asia and Africa were also considered as dhimma. Supporters of this inclusion based their argument on identifying the scriptures of the aforementioned religions with the kitab maknun (hidden scripture) (Quran 56:77-80), with their adherents equally revered as dhimma. Later on, other Muslim thinkers added new dimensions to the principle of religious and cultural tolerance. Among them are Jamal al-Din al-Afghani (1837-1897AD), Muhammad Abduh (1849-1905AD), and Rashid Rida (1865-1935AD). They based their notions on the Quran, traditions and sunna (the common practice). The instruction of Ali Ibn Abi-Talib, who is the first Shi't saint and one of the early Caliphs to succeed the prophet of Islam, to his governor in Egypt, is mentioned in Nahj-al-Balagheh (1998: 278), and provides an example of sunna with regard to the conception of toleration. He orders his governor to show mercy, love, and kindness to all his subjects under his rule, including non-Muslims whom he declared to be "[his] your equals in creation". 


\section{Early Examples of Islamic Tolerance}

There seems not to be an equivalent of dhimma in other religions. Besides, the history of religious tolerance in non-Muslim lands existed as late as the seventeenth century, with the exception of Greece and contemporary Buddhism. Also, landmarks in the history of Christendom such as the Peace of Westphalia and the Toleration Act in England came as late as $1648 \mathrm{AD}$ and $1689 \mathrm{AD}$, respectively. In fact, it took the West centuries for the principle of toleration to be legally accepted. In Europe the pattern of openness appeared, for instance, in the development of Unitarian Toleration in Hungary and its articulation in the Edict of Torda in 1568AD. The situation was fairly better in Spain as it was the most multicultural society in Europe.

The example of Spain is important for the argument here as it is the first instance of the presence of Islam for nearly seven hundred-odd years (711-1492AD) as a political power in Europe. The next important Islamic government which observed tolerance is the Ottoman Empire which ruled for four centuries. It was mostly through Spain, especially by way of Toledo, that the rest of Europe -Latin-Christendom made contacts with the Islamic world. One of the results of this was that Europeans could finally have full access to the vast body of philosophical and scientific materials, which were translated from Greek into Arabic in the Abbasids capital of Baghdad, and brought to Spain by Muslim rulers then. With that knowledge came a culture as well which embraced other monotheistic religions, and created an ethos of toleration which proved to have the capability of accommodating indigenous traditions and cultures, even though sometimes it triumphed and sometimes it failed.

Before the Islamic conquest, the Iberian Peninsula was ruled by Goths, a ruling élite, who were separate from the indigenous people. As Salma Khadra Jayyusi has observed (1994: 5) all high offices were reserved to them and inter-marriage with their subjects was prohibited. When Islam spread across the Iberian Peninsula, some of the Muslim rulers such as Abd al-Rahman III endeavoured to practise the Islamic principle of tolerance, and created a legacy to be followed by some of his successors. While his reign and that of his son and grandson proved to be the most flourishing and tolerant among the Muslim rulers of Spain, the rules of Almohads and Almoravids were associated with far less mutual understanding and respect, as well as interreligious contacts.

The Muslim conquest of the Iberian Peninsula recovered the country from the economic and cultural depression that followed the collapse of Rome. This growth brought about assimilation and even revival of the rich gifts of earlier and indigenous cultures such as the Jewish culture, whose community rose from the ashes of an abysmal existence under the Visigoths to the point where they held high offices at court. In fact, to a great extent Islam moderated anti-Jewish sentiments that existed before. This cultural revival showed itself in several ways, the most significant and enduring of which was the revolution that took place in the history of the Hebrew language in a post-war situation when Abd al-Rahman III, defeated the Jews and Christians, but let them retain their culture and language. The rebirth of the Hebrew language happened by dressing it in Arabic prosody and bringing it to life as a language spoken outside the synagogue and used in poetry. This achievement was initiated by Dunash ben Labrat (920-990AD), commentator, poet and grammarian, and continued by poets such as Samuel the Nagid who wrote poetry in Hebrew. He was also one of the viziers and leaders of the army of the Nasrids, and a descendant of the Mozarabs of Cordoba. The fruits of Muslim religious toleration affected other aspects of the life of Jewish people to the extent that they had the freedom to set their own lunar calendar and holy days. This was done by the head of their community (gaom) who was based in Baghdad by the authority given to him by the state. While in Europe Jewish people were persecuted and deprived of basic human needs, in Spain they led prosperous lives and could benefit from and contribute to the everyday-expanding Arabic library in areas ranging from philosophy, science, medicine, philology, and poetry. 
Not only was the Jewish the only community that benefitted from the fruits of living under a Muslim state. The Christian community had also the opportunity to maintain and improve their language and culture. Menocal (2003: 111) mentions that Mozarabic, which was the mother tongue of the old Christians of Cordoba and of so many other citizens of the caliphate, Muslims and Jews alike, began to be heard alongside Arabic in songs. This revival of the minority languages helped to create a sense of belonging in the Jewish and Christian communities, and motivated them to contribute to the promotion of interreligious contacts in society. Under Muslim rule, religious minorities flourished to be part of the apparatus of translating many books from Greek into Arabic, Latin and Hebrew, and thus making the transfer of knowledge to Europe possible. Michael Scott was one of the renowned translators who were patronised by court. He translated many books such as On Animals by Avicenna, the works of Averroes and Maimonides from Arabic into Latin in 1232AD.

Respect for minorities not only helped towards the development of universal knowledge, but had some immediate results. In the following years, the al-Andalusian society flourished to a point of co-existence, which was unprecedented in the history of Europe, when Christian cities whose Muslim allies helped them defeat Christian rivals became as commonplace as the Muslim taifas whose Christian allies helped them take other Muslim cities. It has been recorded that the famous El-Cid (Rodrigo Diaz) fought in the service of Muslims and Christians alike. The degree of the sense of belonging of religious minorities to the Islamic state of al-Andalusia showed itself in them taking part in the running of the country. Prominent Christians such as the nun Hroswitha (935 - 1002AD) of Grandersheim was in diplomatic circles at the court of Otto I. Also, a bishop, who was known in Arabic as Rabi ibn Zayd, was the caliph's envoy to the court of Otto I. Hasday al-Shaprūt, a Jewish physician at the court of Abd alRahman, was another non-Muslim who held important diplomatic and financial responsibilities at various times. As Menocal (2003: 32) mentions he utilised his public position to look after the interests of the Jewish community not only in al-Andalus but also in Byzantine. The prosperity of the Jewish community was to be dramatically changed with the beginning of the first Crusade, when the Pope ignited a long tradition of organised violence against them in Europe.

Although the reign of other Muslim rulers such as Almohads and Almoravids proved to be far less tolerant than during the time of Abd al-Rahman III, his legacy did not fail to appear in other ways during the reign of his son and grandson. Muslim and Jewish philosophers such as Averroes (in 1126AD), and Maimonides (in 1135AD), who wrote in defence of human freedom a century after Abd al-Rahman III had experienced his legacy during the reign of his grandson. Their writings were a vision of the tolerant world they were born into and which they were educated to take for granted. The legacy of the previous caliphs created a touchstone for religious and cultural tolerance for future generation of rulers and thinkers to be followed centuries later in the Iberian Peninsula and the rest of Europe. The interior of the Cathedral of Cordoba and its Moorish architecture as well as the tomb stone of Ferdinand III of Castile (1199 $-1252 \mathrm{AD}$ ) in the Great Mosque of Seville are tokens of the religious tolerance that existed up until the time of Alfonso in the thirteenth century. When Ferdinand died his son, Alfonso, had his father's tomb inscribed, in the spirit of the age, in three venerable languages of the realm: Arabic, Latin and Hebrew, to take into account the respect for religious diversity in the society he ruled over. Thus, the recognition of the Muslim state of the religio-cultural minorities in Spain then initiated a pattern for tolerance which was one of the main factors that formed the first truly universal culture based on monotheism. The ruling system was supported by an extremely elaborate social, political, and legal organisational structure that was hardly ever seen in Christian states.

Another example of the way Islamic tolerance worked towards establishing solidarity and inclusion in society is the reign of the Ottomans in Turkey. There, it was the basis of the foundation of millet (religious community) system, and helped the government to successfully maintain peaceful religious and ethnic coexistence in a tremendous diverse society for nearly 
four centuries. The Empire, which by the mid-sixteenth century expanded from the Danube to the Nile, from Anatolian lands to the holy cities of Islam, Mecca and Medina, enjoyed stability to the extent that for centuries, it remained free of large-scale religious conflicts. As a result, both the administrative and belief systems of Islam thrived and created a pattern for what we now know as the community organisations and networks for minorities in Western society.

It was the Ottomans' policy to maintain an orthodox and a heterodox form of Islam and make it part of the cultural repertoire of society. Their openness towards non-Muslims was based on the pluralistic nature of the Quranic worldview which is stated in verses such as (49:13) that reads, "Oh humankind, We [God] have created you male and female, and made you into communities and tribes, so that you may know one another. Surely the noblest amongst you in the sight of God is the most God-fearing of you. God is All-knowing and All-aware". This is one of the reasons why there is no conception of 'other' in Islam. The Ottomans were receptive to the use of the knowledge of Byzantine, Christian, Jewish, and Balkan people and allowed for a unique experience of open-mindedness and forbearance. In fact, the Ottomans made no effort to transform differences into sameness; rather, they welcomed cultural and ethnic diversity.

As Barkey (2005) has observed the general prevailing principle in the running of the Empire worked through the coeval use of religious and secular law, that is, the mosque worked within the state rather than outside and opposed to it. In other words, religion functioned as an institution within the state and its practitioners emerged only as state officials called kadi or local magistrates. They were educated in the religious schools and trained in secular and regional law as well as in Sultanic law. Kadis interpreted the religious meanings at local level. The justification of the inclusion of Sultanic law in the Islamic law was that a sovereign and just ruler was indispensible to the application of religious law, and his law was seen as part of the process of its interpretation and practice with regard to various local needs. Kadis were part of the administrative mechanism of the millet system which was a capacious administration of diversity and constructed inter-religious peace in society. It was a script of multi-religious rule and became a normative as well as practical instrument to govern society. This system allowed a loose administrative set of central-local arrangements for Muslim and non-Muslim communities, maintained social boundaries between religious communities and regulated transactions between all the categories involved. By giving significant legal authority and autonomy to each community, the Ottomans maintained the internal religious and cultural composition of them, and involved all members of society in building the Empire. In addition to Muslim communities, there existed three non-Muslim millets: Greek Orthodox, Armenian and Jewish. When there was a strong community organisation or strong ecclesiastical hierarchy in each community, the central state adopted these institutions as the representative structures of the community. All these took place when Christian Europe was still busy with internal religious conflicts and persecution. Although it is highly unlikely that they had no knowledge at all of the cultural and religious diversity that existed in Muslim countries, the question remains why it took them so long to adopt it.

While the fruits of tolerance can be observed in society's composition, such as was seen in Spain and Turkey, they could also lead to mercy at the time of conflict. This is what happened in the most unexpected circumstances during the Second Crusade, which was between Saladin and the Christian army. After winning the war with combined Christian forces including Guy of Lusignan in the Battle of Hattan in 1187AD, Saladin released Guy to join his wife, Queen Sibylla of Jerusalem. He also allowed couples among the hostages to live together in prison to reduce the hardship they suffered from defeat. Unfortunately for mankind, this lesson has still not been learnt. Saladin's mercy was returned by anything but gratitude. In the Third Crusade, Guy, with the help of Richard I of England (Richard the Lionheart), conquered Acre and executed 3000 Muslim prisoners including women and children. It was as late as the sixteenth and seventeenth centuries that the basis of the Geneva Convention, which was to introduce rules for the protection of women and children, made a profound mark on the development of human law in 
the West. Boisard (1980: 443) has observed that while examining the laws applicable in time of war in the seventeenth century, two Spanish Dominicans, Vittoria and Las Cass came across the rulers of Muslim law who treated war hostages as well as the wounded among the enemy as equals. The two Spanish utilised the laws in order to modify the Western law regarding war prisoners.

To conclude, at present, in the adverse situation which is created by political complexities and combined with military interventions, the dominant view about Islam and Muslims is overshadowed by the acts of those minority groups among Muslims who have a literal and Puritanistic reading of Islam. This, to a great extent, has hindered a true understanding of the religion that has contributed significantly to the construction of current patterns of toleration in Western society. The examples chosen above of Islamic tolerance in practice show that from both a theological and historical perspective, Islam has proved to have the capacity to embrace different cultures and religions and to accommodate them. In contemporary history, the continuation of practising the Islamic value of tolerance can still be seen in countries such as Indonesia, where the moral tenet is held to be religious toleration (Pancasila). The recognition of this contribution of Islam to modern society could be a step towards building a tolerant society with more interreligious contacts.

\section{References}

Barkey, K. 2005. Islam and toleration: Studying the Ottoman Imperial model. International Journal of Politics, Culture, and Society 19(1/2): 5-19.

Benthall, J. 2005. Confessional cousins and the Rest: The structure of Islamic toleration. Anthropology Today 21(1): 16-20.

Boisard, M.A. 1980. On the probable influence of Islam on Western public and international law. International Journal of Middle East Studies 11 (4): 429-450.

Galeotti, A.E. 2002. Toleration as recognition. Cambridge: Cambridge University Press.

Huntington, S. P. 1996. The clash of civilizations and the remaking of world order. New York: Simon \& Schuster.

Jayyusi, Salma Khadra (ed.). 1994. The legacy of Muslim Spain. Leiden: E. J. Brill.

Menocal, M.R. 2003. The ornament of the world: How Muslims, Jews, and Christians created a culture of tolerance in Medieval Spain. Boston: Back Bay Books.

Nahj-al-Balagheh: Collected letters and instructions of Ali Ibn Abi-Talib. 1998. Qom: Howzeh Publications.

Zagorin, P. 2003. How the idea of religious toleration came to the West. Princeton: Princeton University Press. 